\title{
A Systemic Conceptual Model to Support Decision- Making in the Sustainability Assessment of Industrial Ecosystems
}

\author{
Dulce Rocío Mota-López, Cuauhtémoc Sánchez-Ramírez, \\ Giner Alor-Hernández, Magno Ángel González Huerta \\ Division of Research and Postgraduate Studies, Instituto Tecnológico de Orizaba, \\ Mexico \\ \{csanchez, galor, magonzalez\}@itorizaba.edu.mx, drociom@ito-depi.edu.mx
}

\begin{abstract}
One of the main challenges for companies is to operate in a sustainable way, that is, by protecting the ecosystems where they are located. As a result of such a challenge, different tools and models have been developed to assess their environmental impact and to help decision makers to define strategies to become more sustainable. However, most of these tools have concentrated on the internal parameters of the companies and have failed to assess the actual impact caused on the ecosystem. Therefore, this article proposes a conceptual model to analyze the environmental risks from companies and evaluate their impact on their ecosystems. Results obtained are: 1) a methodology to assess environmental risks and their impact on the environment and 2) a causal loop diagram that identifies the relationships between the industries and its environment, showing that the company's production rate is the key variable, since it determines the amount of both resources consumed and pollutants emitted, so its balance must be achieved in order to preserve the environment, which, otherwise, will collapse.
\end{abstract}

\section{Introduction}

Growth in population and economic activities - such as agriculture and industrialization - has negative effects on the environment. Therefore, preserving the balance in the exploitation and use of natural resources is crucial to avoid that such growth becomes unsustainable [1]. From this perspective, society, government institutions, and the industrial sector play crucial roles [2]. However, as regards industries, they are prominent actors because of three reasons [3]. First, as producers of goods and services, they are fundamental to satisfy the needs of both actual and future generations. Second, companies are vital to the economic development and wealth of regions. Third, their processes deteriorate the environment and contribute to the depletion of its natural resources.

Recent statistical data have revealed that the demand of natural resources such as water [4] and energy [5], from companies is increasing and will continue to increase. Such increment often exceeds the capacities of these resources to regenerate, not to mention that it also causes the emission of a greater amount of pollutants $[6,7]$. 
Moreover, according to the World Water Assessment Programme [6], if companies maintain their current habits, by 2030 , the world will face a $40 \%$ global water deficit.

This situation reveals that a robust approach must be adopted by industries in order to integrate sustainability into their processes and activities through concrete strategies and actions. Such an approach requires tools to assess the sustainability of these organizations [8] and to help decision and policy makers define the actions needed to reach a more sustainable status $[9,10]$.

According to the literature, the major progresses in industrial sustainable development have been achieved through eco-efficiency based tools [11, 12]. Unfortunately, these eco-efficiency based tools do not seem to provide positive results, since strategies employed merely evaluate parameters inside the company and do not consider the impact caused beyond the operational limits [3]. This implies that new approaches must be developed, and they must allow for a systemic analysis to measure the effectiveness of solutions proposed [13].

The main contribution of this research is therefore a model to assess the sustainability of companies from a systemic approach. The central part of such a model is the analysis of the interactions between the industrial sector and its environment based on water consumption, energy consumption emissions of air pollutants, and emissions of water pollutants. Such factors of environmental impact were selected due to the increasing consumption of water and energy and the high levels of hazardous substances emitted (section 3.1). Likewise, system dynamics (SD) was used to evaluate the model, since such a methodology enables to model different types of systems from the structural analysis of their variables, and this helps understand how systems work and the consequences that may arise from their status $[14,15]$.

As for the structure of this paper, the remaining sections are organized as follows. Section 2 provides an analysis of the most used tools and SD models for sustainability assessment in companies. Section 3 describes the proposed model in this research, while section 4 defines the methodology followed for its application. Eventually, section 5 introduces the causal loop diagram that depicts the interactions between the key variables from the conceptual model. Finally, section 6 presents conclusions and remarks for future work.

\section{Tools for Industrial Sustainability Assessment}

In the literature, a great number of industry-related sustainability assessment tools have been proposed and classified in various categories [2, 9, 16]. For example, [9] classified 48 tools in six categories: 1) individual/set of indicators, 2) composite indices, 3) socially responsible investment indices, 4) material and energy flow analysis, 5) life cycle analysis, and 6) environmental accounting. Likewise, [2] evaluates 16 tools, initiatives and methods for corporations to engage with sustainability. However, the analysis conducted to these tools shows that they do not appropriately reflect the damages caused to the ecological processes of ecosystems or the risks that such damages represent for the further development of companies, due to the fact that are focus on process or products. Tools such as SD, multi-criteria analysis, risk analysis, cost-benefit analysis and environmental impact assessment, allow supporting decision 
A Systemic Conceptual Model to Support Decision-Making in the Sustainability Assessment of ...

making in sustainability assessment and have the potential to analyze the industryecosystem relations, although these tools are not only used for industrial purposes.

Thus, the characteristics that a tool must have to evaluate the environmental impact from companies are the following $[3,8,11]$ :

1) A holistic approach to analyze as a whole all the elements comprised in the industrial and ecological systems.

2) A large spatial scale to adopt regional, national, and international scales without limiting to processes, plants, or products.

Table 1 shows the analysis of the mentioned characteristics in SD, multi-criteria analysis, risk analysis, cost-benefit analysis and environmental impact assessment. For instance, multi-criteria analysis, risk analysis and environmental impact assessment can employ large spatial scales, but they lack a holistic approach. From a different perspective, cost-benefit analysis does not rely on any of the three aforementioned characteristics, while SD includes them all, because it focuses on analyzing the relationships among the variables of the systems and allows for the use of different spatial scales $[15,17,18]$. Therefore, it is employed by this research.

Table 1. Characteristics of the sustainability assessment tools.

\begin{tabular}{cccc}
\hline \multirow{2}{*}{ Authors } & \multirow{2}{*}{ Tools } & \multicolumn{2}{c}{ Characteristics } \\
& & Holistic approach & Spatial scale \\
\hline$[17-19]$ & SD & $\mathrm{X}$ & $\mathrm{X}$ \\
{$[20-22]$} & Multi-criteria analysis & - & $\mathrm{X}$ \\
{$[23-25]$} & Risk analysis & - & $\mathrm{X}$ \\
{$[26,27]$} & Cost-benefit analysis & - & - \\
{$[28-30]$} & Environmental impact assessment & - & $\mathrm{X}$ \\
\hline
\end{tabular}

\subsection{SD Models for Sustainability Assessment}

SD has been widely used to develop simulation models for sustainability assessment in different environmental, social, and economic systems [31].

In the literature several models holistically present the relationships that exist between environmental and socioeconomic systems, assessing the impact of domestic activities on water availability and quality [15, 32-36]; as well as on energy consumption and emissions of $\mathrm{CO} 2$ [37-41].

As for industrial simulation models, they have been applied to a wide range of industries, including the oil and gas sector [42], the automotive industry [43], the cement industry [44, 45], the steel industry [46], and the electric power industry [47]. Such models measure the use of natural resources and the emissions of hazardous substances, although they do not assess the impact caused on the environment.

Conceptual SD simulation models have also been proposed in the literature [14, 48, 49]. These models suggest a set of guidelines to construct them based on the three pillars of sustainability (economic, social and ecologic). In this case, the type of 
environmental impact assessed depends on the user's criteria and the specific problem that is addressed.

Even though SD enables to model the different effects caused by social and economic activities on the environment, the literature review on simulation or conceptual SD models for sustainability assessment of companies shows that they do not integrate such damages caused to the environment.

\section{Conceptual Model for Sustainability Assessment in Emerging Economies}

This section analyzes the four environmental impact factors. These elements are part of the conceptual model proposed to evaluate sustainability, and they will be analyzed by means of a diagram that is part of the proposed model.

\subsection{Environment and Industrial Impact Factors}

Water consumption, energy consumption, emissions of water pollutants, and emissions of air pollutants, are important environmental impact factors [5, 50,51] that contribute to the damage that the industrial sector causes to ecosystems. Their importance for industries is explained below.

Water consumption. Water is essential to industries because it is used for several purposes such as cleansing, heating, cooling, steam generation, ingredient, among others [6]. However, the rise in production and consumption -produced by population growth, urbanization and industrialization- has produced an increasing demand in freshwater, affecting it availability. Thus, it is a priority for industries to secure their access to the resource, especially in a competing environment. Besides, is expected that the world industrial water consumption will be increase by $400 \%$ in 2050 .

Energy consumption. The industrial sector uses energy in activities such as product manufacturing, assembling, steam generation, heating, cooling, lighting of buildings among others; and is considered one of the main worldwide energy consumer [5]. According to the Organization for Economic Co-operation and Development (OECD), the amount of delivered energy in the industrial sector is expected to continue growing in the projection period 2010-2040 [52]. As regards the countries that are part of the OECD, the average increase per year is estimated to be $0.4 \%$. However, for non-OECD members, the percentage increases up to $2.3 \%$ per year.

Emission of water pollutants. Industrial wastewaters are a serious ecological problem because they contain toxic substances that are hard to treat [4]. In developing countries around the $70 \%$ of the industrial wastewater produced is dumped untreated into water bodies, due to the lack of proper legal regulations and industrial investment in technology to treat them [53].

Emission of air pollutants. Industrial pollutants released in the air mainly involve carbon dioxide $\mathrm{CO} 2$. Such pollutants derive from the consumption of energy and the industrial processes of the companies [7]. Since the beginning of the industrial revolution, industrial $\mathrm{CO} 2$ emissions have been increasing, as a consequence of the surge in the use of fossil fuels. This tendency is expected to continue in the future despite the expansion in the use of alternative energy sources [54]. 
A Systemic Conceptual Model to Support Decision-Making in the Sustainability Assessment of ...

\subsection{A Block Diagram of the Conceptual Model for Sustainability Assessment}

Figure 1 shows the interactions between the company under assessment and the ecosystem, based in the environmental impact factors described above. As observed in Figure 1, these interactions work as follows:

1) The environment provides natural resources (water and energy) to the company for its production processes.

2) Companies produce goods and services according to the existing demand.

3) As sub-products of the production processes, air and water pollutants are generated and released into the environment.

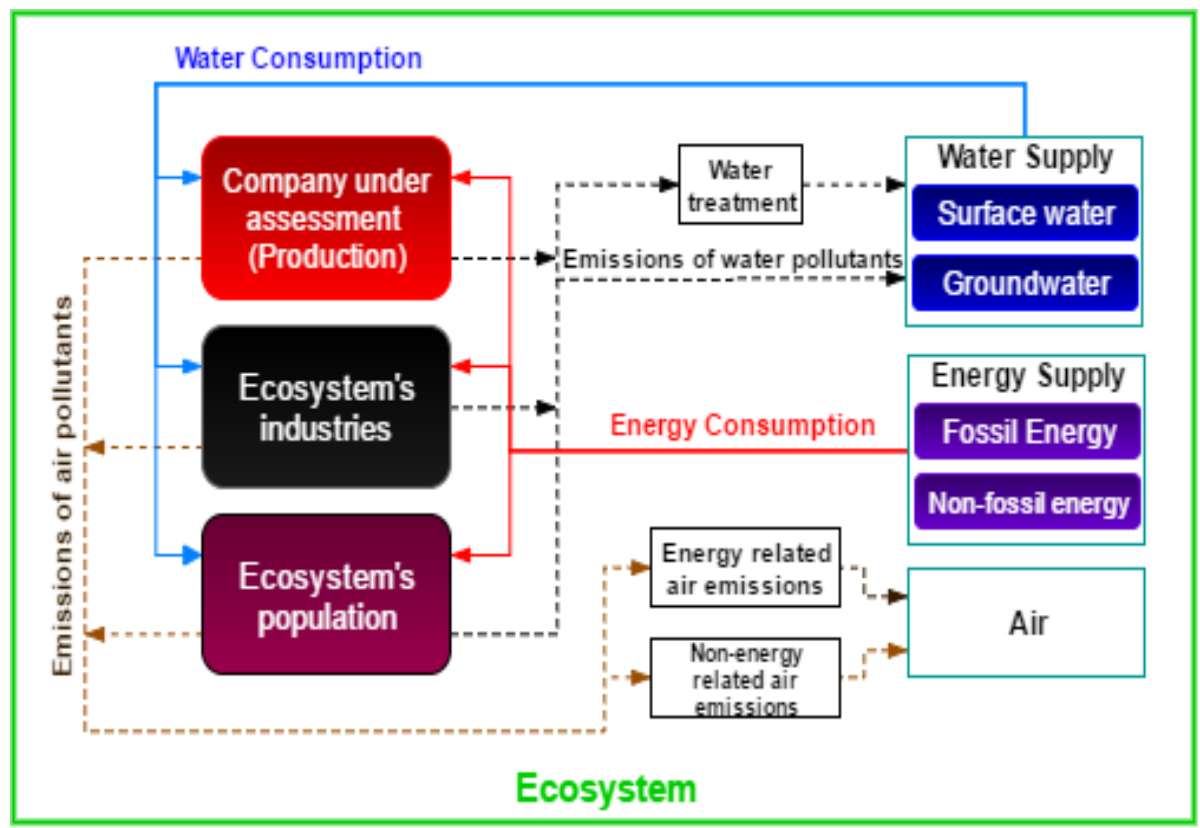

Fig. 1. Conceptual model.

The impact caused on the environment from the industries depends on the amount of natural resources consumed and on the amount of pollutants released and their levels of hazardousness. Thus, in order to improve the sustainability of a company a balance must exist to limit the amount of natural resources that the industry uses and the levels of pollutants that it emits. To guide industrial activities towards a more sustainable performance, one must define ecological limits for the use of natural resources and the emission of pollutants. Such limits ensure the correct functioning of the environment $[9,55]$, which is severely damaged when companies reach or are close to these limits. Moreover, if ecological limits are exceeded, they will seriously affect the ecological processes, which, in turn, will interrupt the industrial activities of companies involved [56]. Otherwise, companies will be responsible for severe water and energy shortages 
and serious environmental degradation. However, a company is not the single actor that damages the environment, since activities from the population and other companies in the same ecosystem also have a negative effect on the environment. Therefore, both sectors are also integrated in the conceptual model.

Finally, it is worth mentioning that this model proposed to assess sustainability enables to know the current status of the environment by indicating the amount of damage caused by the company. From such a result, several strategies can be designed and proposed to diminish damages and guarantee the integrity of the environment and the future of where the model is applied.

\section{$4 \quad$ Methodology Followed to Assess Sustainability}

Figure 2 depicts the steps followed to assess the sustainability level of a company. On the one hand, the first stage is the characterization of the company to assess and its natural environment. On the other hand, the second step consists in developing the SD model. Each one of these stages is described below.

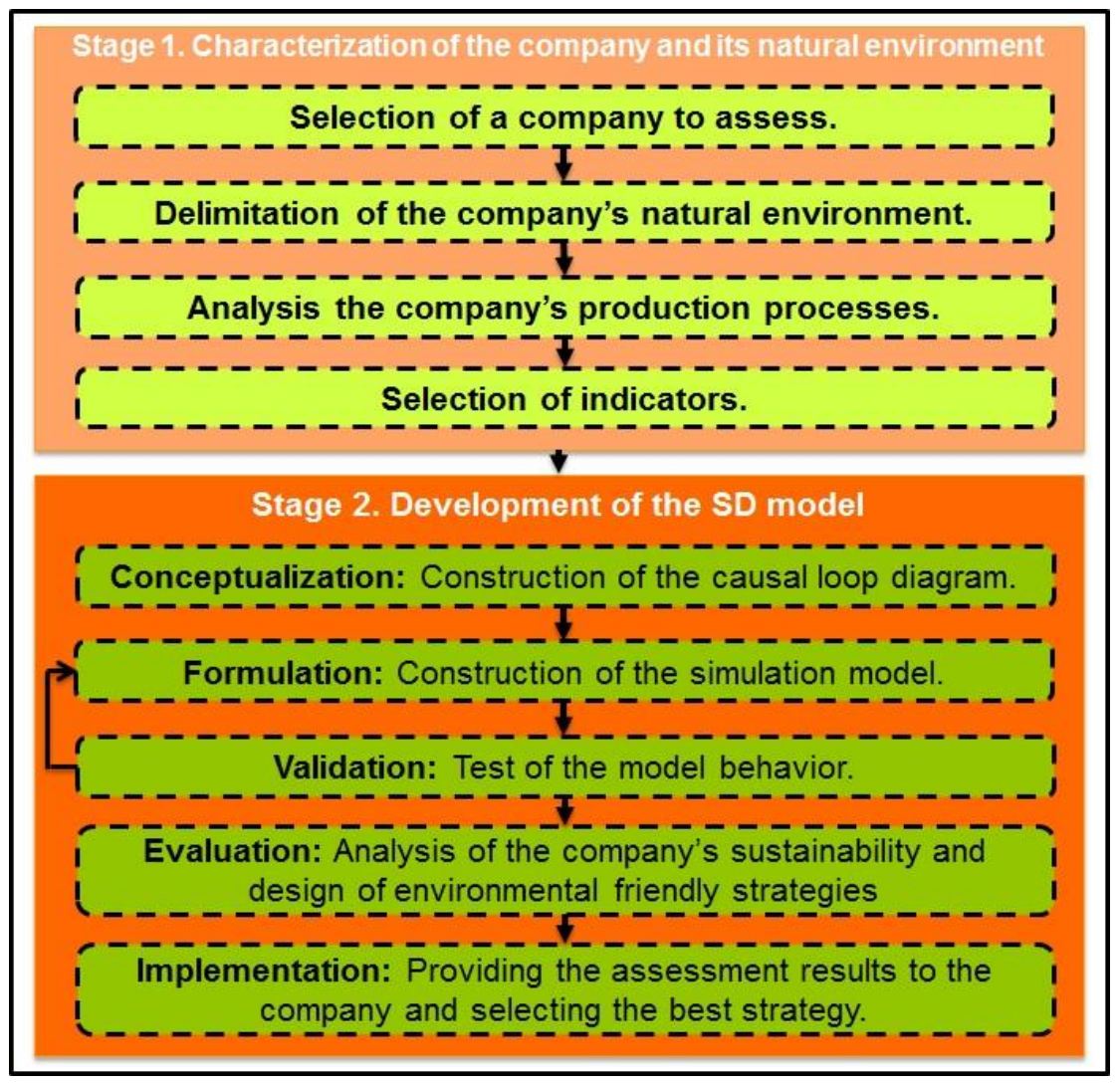

Fig. 2. Methodology to assess industrial ecosystem sustainability. 
A Systemic Conceptual Model to Support Decision-Making in the Sustainability Assessment of ...

\section{Stage 1: Characterization of the Company and its Natural Environment}

This stage comprises four specific activities:

1. Selection of a company to assess: A company is selected to define the level of risk that it poses to the environment based on four factors: water consumption, energy consumption, emission of water pollutants, and emission of air pollutants.

2. Delimitation of the company's natural environment: Delimitating the natural environment affected by a company involves identifying: a) sources of supply of natural resources and processes involved in their availability, and b) sources of emission of air and water pollutants and their environmental impact.

3. Analysis of the company's production processes: This involves identifying the key processes of the company to determine the amount of both natural resources used and pollutants emitted.

4. Selection of indicators: Specific indicators will be selected to both assess the environmental impact of each one of the four factors (water consumption, energy consumption, emissions of water pollutants, and emissions of air pollutants) and define their ecological limits. Such limits will be used as reference to know the level of sustainability of the company.

\section{Stage 2: Development of the SD Model}

The model is developed following the stages described by Sterman (2000) and CedilloCampos and Sánchez-Ramírez (2008) for the creation of SD simulation models

1. Conceptualization: Key variables are selected. These variables represent the different interactions between a company and the environment. They are represented by a causal loop diagram.

2. Formulation: The simulation model (Forrester diagram) is developed based on the causal loop diagram. The system's behavior is described by means of mathematical equations related to the following factors: water consumption, energy consumption, emission of water pollutants, emission of air pollutants, generation of natural resources, and damages caused to these natural resources, among others,

3. Validation: The model is validated through different tests in order to determine whether its structure and behavior are consistent with the system that it represents $[57,58]$ (i.e.: the interactions between the industry and the environment). If results from these tests are not satisfactory, corrections must be made.

4. Evaluation: The level of sustainability of the company is assessed based on results obtained. Similarly, strategies for sustainability improvement are developed, and their effectiveness is tested. Finally, the most suitable strategy is selected.

5. Implementation: Final results are provided to the company and suggestions are offered to implement the most suitable strategy to improve sustainability.

This article presents the first step in the development of a SD model, which is the construction of the causal loop diagram. 


\section{Causal Loop Diagram}

Table 2 lists and defines the variables that compose the causal loop diagram. Let us recall that such a diagram defines the different interactions between a company and the environment (Figure 3 iError! No se encuentra el origen de la referencia.). Note that these variables were identified as key elements to assess the impact of the four environmental impact factors (water consumption, energy consumption, emissions of water pollutants, and emissions of air pollutants) over the environment.

Table 2. Variables of the causal loop diagram.

\begin{tabular}{|c|c|c|}
\hline Authors & Variables & Description \\
\hline$[59,60]$ & $\begin{array}{l}\text { Demand } \\
\text { Company's production rate }\end{array}$ & $\begin{array}{l}\text { Amount of goods and services required by consumers. } \\
\text { Amount of products to manufacture. }\end{array}$ \\
\hline $\begin{array}{l}15,34- \\
36,61,62]\end{array}$ & $\begin{array}{l}\text { Company's water demand } \\
\text { Water consumption } \\
\text { Shortage } \\
\text { Water supply } \\
\text { Surface water } \\
\text { Ground water } \\
\text { Company's emissions to water } \\
\text { Pollutant load } \\
\text { Water quality } \\
\text { Company's water quality requirements } \\
\text { Quality satisfaction } \\
\text { Water with the quality requirements } \\
\text { Water treatment } \\
\text { Water availability for the company }\end{array}$ & $\begin{array}{l}\text { Volume of water required for the industry's processes. } \\
\text { Volume of water consumed in the region. } \\
\text { Environmental impact produced when the water } \\
\text { consumption exceeds the available supply. } \\
\text { Total volume of water provided by surface and } \\
\text { groundwater sources. } \\
\text { Volume of water withdrawn from superficial sources. } \\
\text { Volume of water withdrawn from groundwater sources. } \\
\text { Volume of wastewater produced by the company. } \\
\text { Degree of pollution of wastewater. } \\
\text { Measure of the water's physical and chemical properties } \\
\text { that indicates the environmental impact caused to the } \\
\text { resource. } \\
\text { Parameter that defines the water quality level required } \\
\text { for the company's processes. } \\
\text { Measure that indicates if the ecosystem's water quality } \\
\text { complies with the industry's water quality requirements. } \\
\text { Volume of water that complies with the quality } \\
\text { requirements. } \\
\text { Volume of water treated to remove pollutants. } \\
\text { Volume of water available for the company's processes. }\end{array}$ \\
\hline$[46,63]$ & $\begin{array}{l}\text { Energy consumption } \\
\text { Energy supply } \\
\text { Energy security }\end{array}$ & $\begin{array}{l}\text { Amount of energy used for the company's processes. } \\
\text { Amount of energy supplied to the industry. } \\
\text { Measure that indicates if the company's energy supply } \\
\text { is reliable or not. }\end{array}$ \\
\hline $\begin{array}{l}{[39,44,} \\
45,64]\end{array}$ & $\begin{array}{l}\text { Fossil fuel energy use } \\
\text { Emissions to air related to fossil fuel energy } \\
\text { use } \\
\text { Company's emissions to air } \\
\text { Air quality } \\
\text { Pressure to reduce emissions } \\
\begin{array}{l}\text { Adoption of environmental friendly } \\
\text { alternatives }\end{array}\end{array}$ & $\begin{array}{l}\text { Amount of energy from fossil fuels. } \\
\text { Emissions of air pollutants produced by the use of fossil } \\
\text { fuels. } \\
\text { Pollutant substances released by the company to the } \\
\text { atmosphere. } \\
\text { Measure of the amount of pollutants in the atmosphere } \\
\text { that indicates the environmental impact produced to the } \\
\text { air. } \\
\text { Actions taken to promote the reduction of pollutant } \\
\text { emissions to air. } \\
\text { Alternatives that lead to the reduction of emissions of air } \\
\text { pollutants. }\end{array}$ \\
\hline$[36,61]$ & $\begin{array}{l}\text { Ecosystem's industries water demand } \\
\text { Ecosystem's population water demand } \\
\text { Ecosystem's industries emissions to water } \\
\text { Ecosystem's population emissions to water } \\
\text { Ecosystem's industries energy consumption } \\
\text { Ecosystem's population energy consumption } \\
\text { Ecosystem's industries emissions to air } \\
\text { Ecosystem's population air emissions } \\
\end{array}$ & $\begin{array}{l}\text { Volume of water required by the industries and the } \\
\text { population in the ecosystem. } \\
\text { Volume of wastewater produced by the industries and } \\
\text { the population in the ecosystem. } \\
\text { Amount of energy required by the industries and the } \\
\text { population in the ecosystem. } \\
\text { Volume of air pollutants emissions produced by the } \\
\text { industries and the population in the ecosystem. }\end{array}$ \\
\hline
\end{tabular}


A Systemic Conceptual Model to Support Decision-Making in the Sustainability Assessment of ...

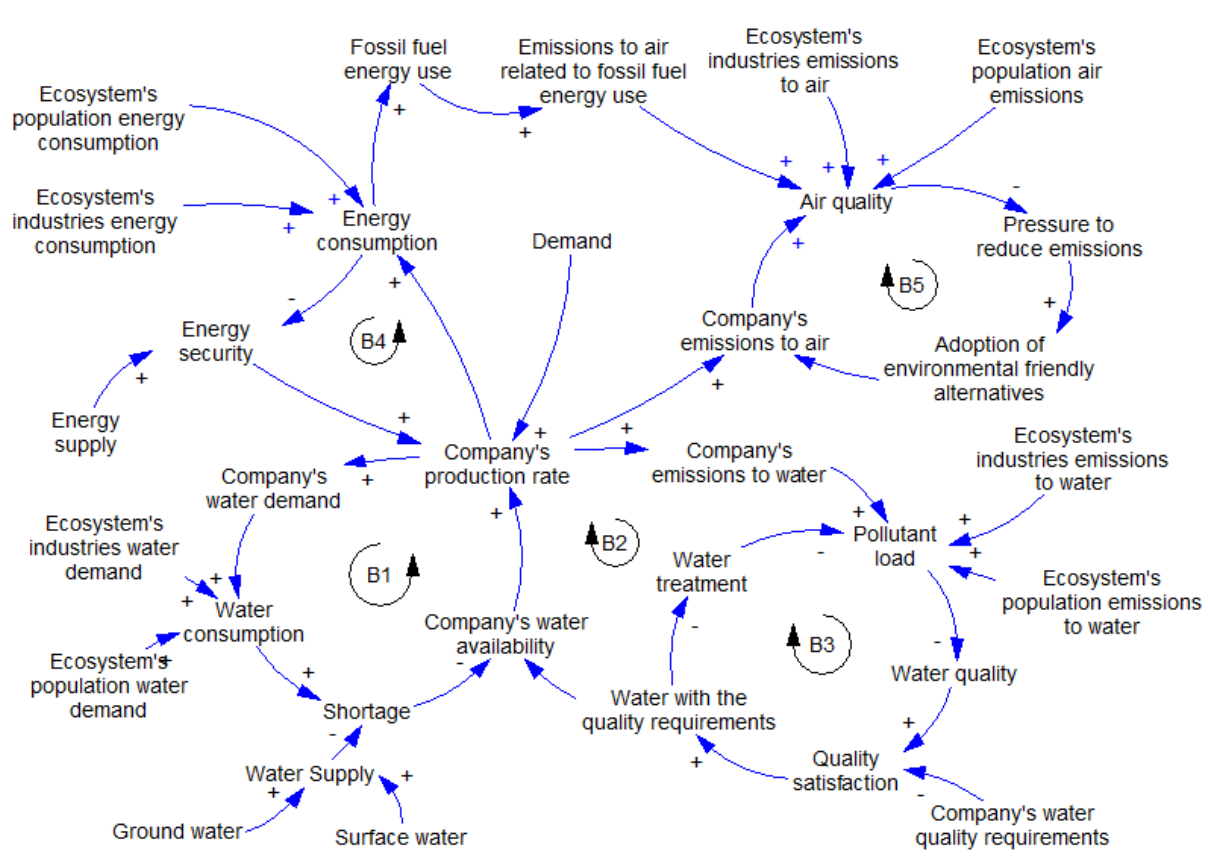

Fig. 3. Causal loop diagram.

The feedback loops from the causal loop diagram that show the interactions produced by the environmental impact factors are analyzed are the following:

B1: The company's production rate defines to a great extent the amount of water that every company consumes. When this factor causes its excessive use, the total water consumption in the environment increases. Therefore, in this case, and within a scenario of industrial growth, water becomes insufficient for the company, since its consumption exceeds its availability.

B5: The company's production rate and the industry sector define to the greatest extent the type and volume of industrial wastewater discharged by companies, since it determines the toxicity and concentration of pollutants found in the discharges. Moreover, the quality of water is essential to the industrial sector, because all industrial processes require specific quality levels of such a resource. Therefore, if these levels are too high, sources to obtain water become scarce, and water available is insufficient.

B7: Energy security allows companies to ensure the correct operation of their production processes at all stages and successfully meet certain requirements. However, the energy security in the industrial sector depends on how much it is consumed. Thus, if the company increases its use of electricity due to higher production rates, energy security will be compromised, and its availability may be interrupted.

B8: Air quality diminishes when the company emits high levels of air pollutants. Such chemicals are the result of several industrial processes and the use of fossil fuels. Therefore, since poor air quality negatively affects human health and ecosystems, the company must develop strategies to reduce their emissions. 
The global analysis of the causal loop diagram shows that the company's production rate is the key variable that influences the four environmental impact factors, and it also becomes affected by those factors. This means that if at least one of them is out of control, the company and their processes will be seriously affected, and their future will be compromised. Therefore, this research highlights that it is important to strive to maintain and ensure a balance between the consumption of natural resources and the emission of pollutants.

\section{Conclusions and Future Work}

By using the SD approach and a causal loop diagram, this research proposes a model that analyzes the following aspects: 1) the uncontrolled interactions between a company and the ecosystem, which are produced by four environmental impact factors: water consumption, energy consumption, emission of water pollutants, and emission of air pollutants, and 2) SD is a tool that enable to model in an integrated manner the different interactions between the company and the ecosystem, because it follows an holistic approach, which allows for the analysis of larger spatial and temporal scales.

Likewise, this new model provides the foundations to construct simulation models for sustainability assessment that efficiently provide information to develop strategies that ensure the conservation of the environment. Similarly, the model demonstrates that environmental damages contribute to a difficult regeneration of natural resources, which hence limits the development and correct operation of companies.

As future work, the conceptual model proposed will be applied in a case study by following the stages described in the methodology section, with the aim of validating the model in its field of application and obtaining feedback about it. Finally, the usefulness of this model can be improved by integrating more environmental impact factors, such as the soil use and the generation of solid waste, among others. This will provide a better understanding and a more complete view of the damages that companies cause to the ecosystems.

\section{References}

1. Hay, L., Duffy, A., Whitfield, R.I.: The Sustainability Cycle and Loop: Models for a more unified understanding of sustainability. J. Environ. Manage, 133, pp. 232-257 (2014)

2. Lozano, R.: Towards better embedding sustainability into companies' systems: An analysis of voluntary corporate initiatives. J. Clean. Prod., 25, pp. 14-26 (2012)

3. Kunz, N.C., Moran, C.J., Kastelle, T.: Conceptualising "coupling" for sustainability implementation in the industrial sector: A review of the field and projection of future research opportunities (2013)

4. WWAP: The United Nations World Water Development Report 4: Managing Water under Uncertainty and Risk, Vol.1, Knowledge Base, Vol. 2, Facing Challenges, Vol. 3 (2012)

5. IEA: International Energy Outlook 2014. , Washington, D.C. (2014)

6. WWAP: The United Nations World Water Development Report: Water for a Sustainable World, Paris (2015)

7. IEA: $\mathrm{CO} 2$ Emissions From Fuel Combustion Highlights, https://www.iea.org/publications/freepublications/publication/CO2EmissionsFromFuelCo mbustionHighlights2014.pdf 
A Systemic Conceptual Model to Support Decision-Making in the Sustainability Assessment of ...

8. Ness, B., Urbel-Piirsalu, E., Anderberg, S., Olsson, L.: Categorising tools for sustainability assessment. Ecol. Econ, 60, pp. 498-508 (2007)

9. Angelakoglou, K., Gaidajis, G.: A review of methods contributing to the assessment of the environmental sustainability of industrial systems. J. Clean. Prod (2015)

10. Singh, R.K., Murty, H.R., Gupta, S.K., Dikshit, A.K.: An overview of sustainability assessment methodologies. Ecol. Indic., 9, pp. 189-212 (2009)

11. Bocken, N.M.P., Short, S.W., Rana, P., Evans, S.: A literature and practice review to identify Sustainable Business Model Element Archetypes. J. Clean. Prod., 65, pp. 42-56 (2014)

12. Huysman, S., Sala, S., Mancini, L., Ardente, F., Alvarenga, R.A.F., De Meester, S., Mathieux, F., Dewulf, J.: Toward a systematized framework for resource efficiency indicators. Resour. Conserv. Recycl., 95, pp. 68-76 (2015)

13. Hjorth, P., Bagheri, A.: Navigating towards sustainable development: A system dynamics approach. Futures, 38, pp. 74-92 (2006)

14. Musango, J.K., Brent, A.C.: A conceptual framework for energy technology sustainability assessment. Energy Sustain. Dev., 15, pp. 84-91 (2011)

15. Zhang, Z., Lu, W.X., Zhao, Y., Song, W.B.: Development tendency analysis and evaluation of the water ecological carrying capacity in the Siping area of Jilin Province in China based on system dynamics and analytic hierarchy process. Ecol. Modell, 275, pp. 9-21 (2014)

16. Moldavska, A., Welo, T.: On the Applicability of Sustainability Assessment Tools in Manufacturing. Procedia CIRP, 29, pp. 621-626 (2015)

17. Forrester, J.W.: Industrial Dynamics. Harv. Bus., Rev. 36, pp. 37-66 (1958)

18. Sterman, J.D.: Business dynamics: Systems thinking and modeling for a complex world. Irwin McGraw-Hill (2000)

19. Cedillo Campos, M.G., Sánchez Ramírez, C.: Análisis Dinámico de Sistemas Industriales. Trillas (2008)

20. Amrina, E., Ramadhani, C., Vilsi, A.L.: A Fuzzy Multi Criteria Approach for Sustainable Manufacturing Evaluation in Cement Industry. Procedia CIRP, 40, pp. 620-625 (2016)

21. Gupta, S., Dangayach, G.S., Singh, A.K., Rao, P.N.: Analytic Hierarchy Process (AHP) Model for Evaluating Sustainable Manufacturing Practices in Indian Electrical Panel Industries. Procedia - Soc. Behav. Sci., 189, pp. 208-216 (2015)

22. Herva, M., Roca, E.: Review of combined approaches and multi-criteria analysis for corporate environmental evaluation. J. Clean. Prod., 39, pp. 355-371 (2013)

23. Li, D., Zhang, C., Pizzol, L., Critto, A., Zhang, H., Lv, S., Marcomini, A.: Regional risk assessment approaches to land planning for industrial polluted areas in China: The Hulunbeier region case study. Environ. Int., 65, pp. 16-32 (2014)

24. Goerlandt, F., Reniers, G.: On the assessment of uncertainty in risk diagrams. Saf. Sci., 84, pp. 67-77 (2016)

25. Izvercian, M., Ivascu, L.: Semantic Assessment of the Risk: A Multidimensional Data Model for Sustainable Enterprise. Procedia Technol., 16, pp. 598-605 (2014)

26. Finnie, B., Stuart, J., Gibson, L., Zabriskie, F.: Balancing environmental and industry sustainability: A case study of the US gold mining industry. J. Environ. Manage, 90, pp. 3690-3699 (2009)

27. Araújo, C., Almeida, M., Bragança, L., Barbosa, J.A.: Cost-benefit analysis method for building solutions. Appl. Energy, 173, pp. 124-133 (2016)

28. Kobayashi, Y., Peters, G.M., Khan, S.J.: Towards More Holistic Environmental Impact Assessment: Hybridisation of Life Cycle Assessment and Quantitative Risk Assessment. Procedia CIRP, 29, pp. 378-383 (2015)

29. Naddeo, V., Belgiorno, V., Zarra, T., Scannapieco, D.: Dynamic and embedded evaluation procedure for strategic environmental assessment. Land use policy, 31, pp. 605-612 (2013)

30. Kusi-Sarpong, S., Sarkis, J., Wang, X.: Assessing green supply chain practices in the Ghanaian mining industry: A framework and evaluation. Int. J. Prod. Econ., pp. 1-17 
Dulce Rocío Mota-López, Cuauhtémoc Sánchez-Ramírez, Giner Alor-Hernández, et al.

(2015)

31. Forrester, J.W.: System dynamics - a personal view of the first fifty years. Syst. Dyn., Rev. 23, pp. 345-358 (2007)

32. Chung, G., Lansey, K., Blowers, P., Brooks, P., Ela, W., Stewart, S., Wilson, P.: A general water supply planning model: Evaluation of decentralized treatment. Environ. Model. Softw., 23, pp. 893-905 (2008)

33. Rehan, R., Knight, M. a, Unger, A. J. A., Haas, C.T.: Financially sustainable management strategies for urban wastewater collection infrastructure - development of a system dynamics model, 7, (2013)

34. Zarghami, M., Akbariyeh, S.: System dynamics modeling for complex urban water systems: Application to the city of Tabriz, Iran. Resour. Conserv. Recycl., 60, pp. 99-106 (2012)

35. Sušnik, J., Vamvakeridou-Lyroudia, L.S., Savić, D.A., Kapelan, Z.: Integrated System Dynamics Modelling for water scarcity assessment: Case study of the Kairouan region. Sci. Total Environ., 440, pp. 290-306 (2012)

36. Mavrommati, G., Bithas, K., Panayiotidis, P.: Operationalizing sustainability in urban coastal systems: A system dynamics analysis. Water Res., 47, pp. 7235-7250 (2013)

37. Guan, D., Gao, W., Su, W., Li, H., Hokao, K.: Modeling and dynamic assessment of urban economy-resource-environment system with a coupled system dynamics - Geographic information system model. Ecol. Indic., 11, pp. 1333-1344 (2011)

38. Jin, W., Xu, L., Yang, Z.: Modeling a policy making framework for urban sustainability: Incorporating system dynamics into the Ecological Footprint. Ecol. Econ., 68, pp. 29382949 (2009)

39. Feng, Y.Y., Chen, S.Q., Zhang, L.X.: System dynamics modeling for urban energy consumption and $\mathrm{CO} 2$ emissions: A case study of Beijing, China. Ecol. Modell., 252, pp. 44-52 (2013)

40. $\mathrm{Wu}, \mathrm{Z} ., \mathrm{Xu}, \mathrm{J} .:$ Predicting and optimization of energy consumption using system dynamicsfuzzy multiple objective programming in world heritage areas. Energy, 49, pp. 19-31 (2013)

41. Robalino-López, A., Mena-Nieto, A., García-Ramos, J.E.: System dynamics modeling for renewable energy and CO2 emissions: A case study of Ecuador. Energy Sustain. Dev., 20, pp. 11-20 (2014)

42. Kiani, B., Ali Pourfakhraei, M.: A system dynamic model for production and consumption policy in Iran oil and gas sector. Energy Policy, 38, pp. 7764-7774 (2010)

43. Abduaziz, O., Cheng, J.K., Tahar, R.M., Varma, R.: A hybrid Simulation model for Green Logistics Assessment in Automotive Industry. Procedia Eng., 100, pp. 960-969 (2015)

44. Ansari, N., Seifi, A.: A system dynamics model for analyzing energy consumption and $\mathrm{CO} 2$ emission in Iranian cement industry under various production and export scenarios. Energy Policy, 58, pp. 75-89 (2013)

45. Anand, S., Vrat, P., Dahiya, R.P.: Application of a system dynamics approach for assessment and mitigation of $\mathrm{CO} 2$ emissions from the cement industry. J. Environ. Manage, 79, pp. 383-398 (2006)

46. Ansari, N., Seifi, A.: A system dynamics analysis of energy consumption and corrective policies in Iranian iron and steel industry. Energy, 43, pp. 334-343 (2012)

47. Saysel, A.K., Hekimoğlu, M.: Exploring the options for carbon dioxide mitigation in Turkish electric power industry: System dynamics approach. Energy Policy, 60, pp. 675$686(2013)$

48. Kibira, D., Jain, S., McLean, C.R.: A System Dynamics Modeling Framework for Sustainable Manufacturing (2009)

49. Zhang, H., Calvo-Amodio, J., Haapala, K.R.: A conceptual model for assisting sustainable manufacturing through system dynamics. J. Manuf. Syst., 32, pp. 543-549 (2013)

50. WWPA: The United Nations World Water Development Report 2015: Water for a 
Sustainable World, Paris (2012).

51. IEA: Worldwide Trends in Energy Efficiency: Key Insights from IEA Indicator Analysis, https://www.iea.org/publications/freepublications/publication/Indicators_2008.pdf

52. IEA: $\mathrm{CO} 2$ Emissions From Fuel Combustion Highlights, https://www.iea.org/publications/freepublications/publication/CO2EmissionsFromFuelCo mbustionHighlights2014.pdf

53. UN-Water: Wastewater Management - A UN-Water analytical Brief, http://www.unwater.org/publications/publications-detail/en/c/275896

54. IEA: Tracking Industrial Energy Efficiency and $\mathrm{CO} 2$ Emissions, https://www.iea.org/publications/freepublications/publication/tracking_emissions.pdf

55. Bithas, K.: Tracing operational conditions for the Ecologically Sustainable Economic Development: The Pareto optimality and the preservation of the biological crucial levels. Environ. Dev. Sustain, 10, pp. 373-390 (2008)

56. Bithas, K., Nijkamp, P.: Biological integrity as a prerequisite for sustainable development : A bioeconomic perspective Research Memorandum 2013-9 Kostas Bithas (2013)

57. Forrester, J.W., Senge, P.M.: Tests for building confidence in system dynamics models, (1980)

58. Qudrat-Ullah, H., Seong, B.S.: How to do structural validity of a system dynamics type simulation model: The case of an energy policy model. Energy Policy, 38, pp. 2216-2224 (2010)

59. Musango, J.K., Brent, A.C., Amigun, B., Pretorius, L., Müller, H.: A system dynamics approach to technology sustainability assessment: The case of biodiesel developments in South Africa. Technovation, 32, pp. 639-651 (2012)

60. Al-Sharrah, G., Elkamel, A., Almanssoor, A.: Sustainability indicators for decision-making and optimisation in the process industry: The case of the petrochemical industry. Chem. Eng. Sci., 65, pp. 1452-1461 (2010)

61. Liu, H., Benoit, G., Liu, T., Liu, Y., Guo, H.: An integrated system dynamics model developed for managing lake water quality at the watershed scale. J. Environ. Manage, 155, pp. 11-23 (2015)

62. Madani, K., Mariño, M.A.: System dynamics analysis for managing Iran's Zayandeh-rud river basin. Water Resour. Manag., 23, pp. 2163-2187 (2009)

63. Aslani, A., Helo, P., Naaranoja, M.: Role of renewable energy policies in energy dependency in Finland: System dynamics approach. Appl. Energy, 113, pp. 758-765 (2014)

64. Lee, S., Geum, Y., Lee, H., Park, Y.: Dynamic and multidimensional measurement of product-service system (PSS) sustainability: A triple bottom line (TBL)-based system dynamics approach. J. Clean. Prod., 32, pp. 173-182 (2012) 